\title{
The Ford Foundation And Development Of Western Education In Nigeria: A Historical Evaluation
}

\author{
Adeoti Ezekiel Oladele, PhD
}

doi: 10.19044/esj.2016.v12n10p315 URL:http://dx.doi.org/10.19044/esj.2016.v12n10p315

\begin{abstract}
The Post World War II years witnessed increasing involvement of international Non-Governmental Organizations (NGOs) in the social and economic transfiguration of the Third World nations. Nigeria as a developing economy did attract the attention of the Ford Foundation to the development of her social sector particularly. The paper examined the Ford Foundation engagements in all facets of the Nigerian educational system, namely, primary, secondary and tertiary levels. The resultant findings revealed that despite its constraints, the huge investments of the Ford Foundation in the areas of comprehensive high school education, teaching and research as well as information and communication technology, no doubt, helped in identifying and nurturing the potentials of Nigerian students for academic, technical or general education. The paper concluded that the involvement of the Ford Foundation in Nigerian educational development helped, in no small way, in re-directing the course of Nigeria's educational system. It recommended that Nigeria government should redouble its efforts towards providing an enabling environment that will attract more credible NGOs like Ford Foundation and encourage them to play effective role not only within the educational sector but also in other key sectors such as agriculture, health, science and technology to assist the country achieve the much touted Millennium Development Goals.
\end{abstract}

Keywords: Non-Governmental Organizations, Ford Foundation, Education, Funding, Nigeria, Millennium Development Goals

\section{Introduction: NGOs as Partners in Development Process}

In international arena, states undoubtedly, are the most significant actors. However, contemporary international relations extends beyond the interactions of national governments. Non - state actors such as Multinational Corporations (MNCs), Non-Governmental Organizations (NGOs) and International Non-Governmental Organizations (INGOs) exert a 
great deal of influence on the international system (J.S. Goldstein \& J.C. Pevehouse, 2006:13-14). Increasingly, formal government relations in recent times have become supplemented by the activities of these non - state actors. Although, they have neither sovereignty nor territory, nonetheless, these NGOs have profound impact on the contemporary global system (O. Ojo \& A. Sesay, 1988: 48-57). International relations, more than ever before, is fast witnessing an upsurge in the activities of NGOs as they perform some crucial developmental roles that are either neglected by the states or those responsibilities that states cannot sufficiently handle. Today, NGOs deliver more official development assistance than the entire United Nations, excluding the World Bank and the International Monetary Fund (IMF) (J.A. Robert \& J. Robert (eds), 1993:541). They play important role in redirecting the focus of the societies where they register their presence. Against this background, this work evaluates the contributions of the Ford Foundation, an international NGO, to educational development in Nigeria through 1958 to 2007.

\section{The Origin and Mission of The Ford Foundation}

The Ford Foundation was founded by Henry and Hdsel Ford of America in 1936 with an initial gift of 25 thousand United States Dollars. At the beginning, the Foundation restricted its operation to the State of Michigan United States of America. By 1950, the Foundation expanded its scope to cover national and international arenas. Initially, the Ford Foundation took interest in the work of the United Nations (UN); it also donated generously towards strengthening the operational activities of the UN as it realized that making the UN more effective would bring about world peace and the establishment of a new world order of law and justice. Apart from supporting the UN, it has made grants available to organizations and governments to carry out specific developmental projects that would benefit a larger percentage of the citizens in their respective countries.

\section{The Advent and Goal of Ford Foundation in Nigeria}

The Ford Foundation (Nigeria) first came into Nigeria in 1958 and immediately took active part in the training of some public service professionals as part of the preparations for Nigeria's independence in 1960. The Foundation has a regional office in Lagos from where over 600 grants totaling about $\$ 250$ million have been disbursed to corporate bodies, institutions and individuals throughout the country since 1958.

The Lagos office, which also doubles as the Foundation's West African regional office is headed by a representative who works with the programme administrative staff made up of both Nigerians and expatriates. 
These officials are responsible for the disbursement of grants with the primary objective of achieving the following:

(i) To strengthen the institutional and cultural foundations of human rights and democratic governance;

(ii) To promote the arts and culture as resources for, and expressions of human development;

(iii) To improve the quality of women's health and social status and

(iv) To enhance the livelihoods of the poor and promote sustainable management of natural resources

The Foundation pursues its objectives mainly by giving monetary aids aimed at promoting knowledge and strengthening organizations and networks in the West African sub-region. Since it's inception in 1958, the Ford Foundation has been involved in many developmental projects in Nigeria in critical areas like Education, Health and Agriculture. However, this study focuses on the Foundation's contributions to the development of education in Nigeria. (Ford Foundation: Global Offices, (http//fordfoundation.org/about/missions.cfm).

Education is critical to human capital development but even more critical for the development of humane values. Education impacts literacy, numeracy, gives greater ability to logical thinking and intelligent adaptability. Education promotes a higher degree of efficiency, innovation and self confidence and enables the individual to acquire a world-class status and mindset. Education is certainly not a panacea for all problems but, as a former American President, Lyndon B. Johnson once said “... without education, no cure for any problem is possible" (Grace Alele-Williams, 2000). Ideas and beliefs like these perhaps motivated the Ford Foundation to take more than a passing interest in the educational development of Nigeria.

\section{The Contribution of Ford Foundation To Educational Development in Nigeria}

One area in which the Foundation made an early impact is secondary education. Immediately after independence, it collaborated with the former Western Regional government in establishing the first Comprehensive Secondary School in Aiyetoro and another at Port Harcourt for the Eastern region. These were set up as pilot projects in the hope that the comprehensive secondary school would become the general pattern of secondary education. The Aiyetoro High School was established and heavily financed by the Ford Foundation and staffed with Americans and Nigerians. The curriculum based on the British, American and Swedish experience was wide and comprehensive. The Objective was to provide a secondary school where admission was not necessarily based on merit but to open the school 
to all children who had completed primary school education (C.O. Taiwo, 1980:40).

The school provided educational opportunities for all children within a given radius of Aiyetoro. These children were then streamed into mainly academic and technical arms. It was very much like the American High School system, where there was also a third stream for those who might not go for scientific or technical education but would receive secondary education that would benefit them in different ways as envisaged by the newly independent Nigeria (Oral Interview with Prof. Grace Alele-Williams, 25 August, 2005).

The Ford Foundation organized many workshops and seminars for teachers in the early 60s to promote the idea of comprehensive schools. The workshops concentrated on the psychological needs of students, improved teaching habits for secondary school teachers as well as administrative competences required to set up such large schools to meet the needs of all secondary school children.

The Aiyetoro Comprehensive High School as a model was too expensive to establish and run. The idea of admitting without an entrance examination children from only the neighbourhood of the school in the usual way of a comprehensive school was soon found unrealistic and unjust in a society where secondary school places were insufficient and admission was highly competitive. Admission to Aiyetoro was won by competitive entrance examination and an essential feature of a comprehensive High school was shed. Moreover, parents preferred to know that their children would complete the course in the school and not be compelled to withdraw during the course (C.O. Taiwo, 1980:140).

The experiment continued for several years. However, in the course of the experiment, it became apparent that most parents considered their children as failures if they were not in the academic arm.

The Western Region could not maintain such high level school in spite of the fact that the science and technical sections were administered and funded by the Ford Foundation. Consequently, within a decade the original vision behind the comprehensive education scheme had waned. As the region could not sustain the original ideals, most students were admitted not from the geographical area as initially planned but on the choice of the administrators in the region.

However, it is to the credit of Ford Foundation that the idea of a comprehensive secondary school that would identify and nurture the potentials of students for academic, technical or general education in Nigeria came about.

Aiyetoro remains a type of its own, a good school but not copied elsewhere. The Aiyetoro experiment and the participation of a large number 
of staff from secondary and tertiary institutions as well as administrative personnel in fashioning a new policy in education culminated in the introduction of a comprehensive high school system in Nigeria (Oral Interview with Dr. Dapo Thomas, 2015).

The Ford Foundation also gave immense assistance to the education ministries in Northern Nigeria to promote activities relating to increasing the number of girls as well as retaining them in schools. This is against the backdrop of the wide gap between the number of boys and girls in schools. According to the Federal Office of Statistics, only 58.2\% of male adults were literate and could read or write with understanding in any one language, local or foreign, while only an average of $41.3 \%$ of female adults were literate in any one language (Oral Interview with Prof. Grace Alele-Williams, 2005). Moreover, the Islamic social custom which requires a certain amount of seclusion of the womenfolk and the observance of the purdah (Otonti Nduka, 1964:60) constituted a barrier to the growth of girls' education in Northern Nigeria. In view of this, the Foundation provided financial and technical aids in the North to reduce the rate of girls' drop-out from schools and to increase the admission of girls into secondary schools. Today, the lives of so many women and children have improved considerably given the enormous jobs done by the Ford Foundation in Northern Nigeria. Assistance was also provided for the Education ministry to hold workshops in order to improve the quality of technical education in Nigeria.

Apart from helping to establish the first comprehensive high school in Nigeria, the Ford Foundation also assisted also in the area of Higher Education (HE) systems in Nigeria with a view to addressing a number of key developmental challenges confronting the sector.

In addition, the Ford Foundation gave financial and technical support towards the establishment of the old Yaba Technical College and the successful take-off of a College of Education at the University of Lagos headed by Professor C.O. Taiwo, renowned professor of Mathematics (Oral Interview with Prof. C.O. Taiwo, 1992); this helped in the production of qualitative professional teachers for primary and post primary schools in Nigeria. The Foundation also donated blocks of flats popularly called "Ford Flats" to many Nigerian universities. These buildings were used as official quarters for the visiting American scholars and researchers whenever they came to Nigeria on linkage programmes. Similarly, the body promoted research activities in the Social Sciences and African Studies programme. It also offered scholarships to many Nigerian students in selected disciplines for advanced studies in many universities in the United States (M.M. Ogbeidi, 2003: 207).

As from 2002, the Ford Foundation began a more systematic engagement of $\mathrm{HE}$ issues in Nigeria within the framework of the African 
Higher Education Initiative (AHEI) with a focus on three main problems addressed on a system-wide, rather than individual university, basis, these problems include:

- $\quad$ sustainable financing of and broadening of access to higher education - $\quad$ improving the quality and relevance of university curriculum, and

- $\quad$ improving the governance and management of universities (Ford Foundation Report, 2001-2005) .

Thus far, the Ford Foundation made five AHEI grants available in 2001, drawing from general reserves (AHEI) allocations and regular office appropriations. The specific issues addressed by theses grants included:

- $\quad$ the enhancement of the capacity of Universities to build and manage endowments

- $\quad$ resuscitation of university-based scholarly publishing

- $\quad$ management and leadership development interventions to engender good governance of Nigerian Universities and

- $\quad$ the enhancement of Information and Communication Technology (ICT) application to Universities-based research and teaching (Ford Foundation Report, 2001-2005)..

By 2001, the Foundation had disbursed grants to the Endowment Consortium Foundation (ECF) in Lagos to execute some development projects between 2001 and 2005. The grants were made in the following manner:

A total sum of $\$ 375,000$ was made available to ensure general support for training, technical assistance and capacity building with respect to endowment building and investment management for Universities in Nigeria, while \$150,000 was provided to help strengthen Nigerian tertiary institutions' endowment building and investment management capacity (Ford Foundation Report, 2001-2005).

In order to achieve the above stated objectives, the Endowment Consortium Foundation carried out the following: firstly, it organized seminars where the management and relevant staff of 23 Universities, on endowment building and management were present and sensitized. Secondly, it embarked on study tours of South African Universities with successful endowment programmes, thirdly, a peer learning group around University endowments was established and, fourthly, it assisted some universities to set up electronic alumni databases and professionalized endowment management units.

Between 2003 and 2005 a grant of $\$ 516,810$ was given also to Bellagio Publishing Network in Oxford, to assess needs, capacity building and publishing/distribution support activities to resuscitate University based scholarly publishing in Nigeria (Ford Foundation Report, 2001-2005). 
Accordingly, the Bellagio Publishing Network conducted and disseminated among key stake holders, the most compressive assessment to date about the state of scholarly publishing in Nigerian Universities. Apart from this, it also developed via a participatory process, a scholarly publishing development plan for some Universities in Nigeria.

Another grant of about $\$ 350,000$ was given to the Centre for Management Development (CMD) in Lagos to carry out management and leadership development activities that would engender good governance in Nigerian Universities. Consequently, the Centre for Management and Development conducted needs assessment and elicited buy-in from participating Universities regarding their management development needs and the required capacity building interventions (Ford Foundation Report, 2001-2005).

The AfriHUB Nigeria Limited in Abuja, also received a sum of \$325,000 from the Ford Foundation, to establish a public-private partnership project that will expand access to ICTs for teaching and research by students and faculty members of some selected Universities and Polytechnics in Nigeria (Ford Foundation Report, 2001-2005).

With the grant, The AfriHUB successfully established a model University ICT parts at the State University in Akwa, Anambra State, South - East, Nigeria. It also commenced training programme as a test case for extending same to one University each in the South - West, South-South and North East zones of Nigeria.

The Foundation also secured financial assistance to some selected tertiary institutions in Nigeria to establish research centers within their campuses where academics as well as students could carry out researches in various disciplines. Some of the Universities which benefited from this gesture included the University of Jos, Lagos State University (LASU) etc.

In November, 2000, the Ford Foundation made a grant of $\$ 300,000$ available as its contribution towards establishing the Centre for Development and Democratic Studies (CDDS) at the Lagos State University, (LASU). The CDDS is a Ford initiative on academic development and governance and policy development research and consultancy services, public policy advocacy and civil society's support for peace efforts (I.A. Adalemo, 2002).

The Ford's grant to LASU was comprehensive in scope and its purpose was to create an African Centre of excellence in development and statecraft. The Foundation made finance available for the centre's programme which include:

- $\quad$ the publication of a reference academic journal

- $\quad$ monthly Seminars culminating in the CDDS Book Series;

- $\quad$ annual International Conference 
- $\quad$ LASU/CDDS Annual Lecture resulting in the publication of CDDS Monograph Series;

- the Organization of a website

- $\quad$ the financing of coordinated research by CDDS associates of young but brilliant academics form various Universities in Nigeria

- $\quad$ the involvement of some recognized civil, societal, non governmental organizations in Nigeria and Internationally (I.A. Adalemo, 2002).

The Foundation also made provisions for

- $\quad$ an international advisory board;

- $\quad$ collaborating research institutions in Nigeria and

- $\quad$ collaborating NGOs and research associates

The Centre was also designed to present monthly lectures. These lectures would afford the Centre the opportunity to examine the political, economic and social problems in Nigeria and Africa as a whole with a view to proposing solutions to them. Professor John Amoda Moyibi served as the Director General of the Centre (Oral Interview with Mr. Ezekiel Ojeniyi) coordinating its activities. How well this has translated to reality is another matter for serious academic debate (I.A. Adalemo, 2002).

Another area where the Ford Foundation registered it's presence is library development. In 1964, the National Library was established by an Act of legislation with Ford Foundation funding. This brought about the comprehensive collection of books relating to Nigeria and Nigerian peoples, for present and future use as part of Nigeria's national heritage. It also made possible the provision of bibliographic services and research facilities as well as staff development for expanding library services in Nigeria (T.N. Tamuno \& J.A. Atanda, 1989:195).

\section{An Assessment of the Impact of Ford Foundation on Education in Nigeria}

For now it is still difficult to ascertain the cumulative impact of the Ford Foundation's grants on the University system in Nigeria. However, it is clear that a huge need exists across different strata of the University system and some of the external stake holders, such as The Ford Foundation, are supporting the African Higher Education Initiative (AHEI) so as to ensure a systematic educational development in Nigeria.

Presently, the process of professionalizing endowment building and management by Nigerian Universities has taken root with some Universities now devoting significant internal resources to it. Also, some segments of the organized private sector and the relevant regulatory agencies have expressed interest in and contributed financially to some of the efforts that were engendered by AHEI grants, such as the contribution of a leading consulting 
firm, Accenture, and the development of alumni databases for 3 Nigerian Universities in support of their endowment building efforts (Oral Interview with Mr. Ezekiel Ojeyemi).

Another important impact of the Foundation's grant - making initiative, particularly to AfriHUB Nigeria Limited is to foster public private partnership in the process of expanding access to ICTs for learning and research by University students and teachers has produced a positive reaction within the country. For instance, the Nigerian Universities Commission (NUC) and Nigeria's leading indigenous computer manufacturer, Zinox Computers Limited have started working together in the area of making many Nigerian Universities to be ICT compliant (Ford Foundation Report, 2001-2005).

Although the changes in the educational system are best measured overtime, there are indications to show that tertiary level of education in Nigeria has been undergoing dramatic changes within the last 4 decades, in order to meet the challenges of Nigerian environment.

One will notice that the Universities' curriculum has been redesigned to include such disciplines that will help accelerate the pace of Nigerian economic and national development (Adamu Baike \& Osaren S.B. Omoregie, 1989:291). For instance, until 1996, the Department of History and International Studies in LASU was known as the History Department, but it later changed to History and International Studies in line with the need to make the department more relevant to contemporary needs (LASU History Department Brochure, 2000-2002:ii). This innovation has since been copied in virtually all Nigerian Universities running History programmes. In the same vein, Law as a discipline is now combined with international politics; chemistry as a subject is now combined with industry to become Industrial Chemistry in some tertiary institutions in the country.

\section{Challenges Confronting the Body}

Having examined some of the contributions of the Ford Foundation towards educational development in Nigeria, it is important to also highlight the foundations constraints and limitations in the discharge of its duties in Nigeria. Some of these constraints and limitations include: insufficient funding, political instability in Nigeria and, unnecessary executive interference.

\section{Poor Funding}

Lack of sufficient local funding is one of the greatest constraints of the Foundation. Owing to this, execution of various projects was either not well carried out or after completion it became a problem to maintain them. This is especially true of the Aiyetoro Comprehensive High School 
experiment in the early 60s. Despite the fact that the experiment was highly beneficial to the children as a new educational innovation, its ideals began to wane a few years after its establishment and this ultimately led to its demise about a decade after it took off (The Ford Foundation Bulletin African Region, No. 27, 1989:17).

\section{Political Instability}

The Issue of political instability in Nigeria at various times especially during military regime had tended to truncate the process of actualizing any meaningful development projects. For instance, the instability which followed the 1966 coup and counter - coup in Nigeria discouraged any substantial project to be carried out by the Foundation. As a matter of fact, this dealt a serious blow to the Aiyetoro Comprehensive High School experiment, as its expatriate staff had to leave the country as a result of the Nigerian civil war, 1967-1970.

Another major constraint to the full implementation of the Ford Foundation's objectives in Nigeria is the issue of hostile administrations that often emerged to initiate policies and programmes aimed at frustrating the efforts of the Foundation. For instance, during General Abacha's regime, 1993 - 1998, the Ford Foundation was confronted with serious challenges when it decided to sponsor seminars that focused on democracy and democratic practices in Nigeria. Such activities were considered by the government of General Sanni Abacha to be inimical to the aspirations of the regime and therefore not allowed to flourish.

\section{Conclusion}

From the foregoing, there is no doubt that the involvement of the Ford Foundation in Nigeria's educational development helped in no small way in re-directing the course of Nigeria's education system. The establishment of the Aiyetoro Comprehensive High School became an eye opener for the newly independent Nigeria and thus made the country to embrace the concept of comprehensive education in her national policy on education. At one time, it appeared as if the country was going comprehensive. Every government advocated it and some schools were converted to comprehensive schools. However, the comprehensive type has not caught on. Even the 6334 system of education which was introduced into the country's educational system in the 80s did not last long due to lack of logistics. Most of the so-called comprehensive schools that emerged in the 60s and 70s have reverted to the grammar school type and a few to the multilateral type with the grammar and the commercial types running in the same school. The Aiyetoro experiment remains a day-dream, an excellent model, a wonderful experiment but not successfully copied elsewhere. However, the 
idea may have influenced the establishment of technical schools, trade centres and polytechnics across the country in the 70s and 80s.

It may also be argued that, given its length of stay in Nigeria, the Ford Foundation has done very little when compared to what it did for the state of Israel and other developing countries in Asia, Latin America and the Pacific. (The Ford Foundation and the United Nations http://www.fordfound.org/elibrary/document/0221.suppress/low/0221 supp.low.pdf) The Ford Foundation and the United Nations, it should be noted that the Ford Foundation like the other organizations involved in the Nigerian project, was not immuned to such destabilizing factors as political instability and unnecessary executive interference in matters affecting its activities in Nigeria. Hence, the performance of the Foundation should be judged within the pervasive economic and political climate of the country in which it found itself. There is no doubt, that given a favourable environment and cooperation of the Nigerian State, the Foundation's lofty educational objective for development of education in Nigeria can still be attained.

Similarly, the establishment of research centres by Ford Foundation and generous funding of same within selected tertiary institutions by Ford Foundation Nigeria has helped in facilitating studies in such areas as democracy and democratization, good governance, public policy advocacy, civil societal organizations, human rights, etc.

By way of recommendation, we may note that Nigeria is a very big country with an estimated population of about 170 million people. Its educational statistics shows that illiteracy is still very high among the urban and rural poor. Hence, the Federal and state governments of Nigeria should pay more attention to education as this is the most important means of accelerating growth and development of the country in all sectors of the economy and national life.

Government should redouble its efforts towards providing an enabling environment that would attract more reputable foreign NonGovernmental Organizations like the Ford Foundation into the country.

More importantly, government at all levels in Nigeria should cooperate with the Ford Foundation and encourage her the more to play a more effective role not only within the educational sector but also in other key areas such as agriculture, health, science and technology, etc. so as to be able to achieve the much publicized Millennium Development Goals (MDGs).

\section{References:}

Adalemo, Isaac Ayinde (2002), “Land Management, Export Crop orientation and food security: An Expository Analysis of an Imminent Crisis”, A Paper Presented at the First CDDS/LASU Monthly Lecture at the Nigerian Institute of International Affairs (NIIA). 
Ogbeidi, M.M. (2003) "Nigeria- US relations: A Historical Overview of American Education in Nigeria, 1900-1980 in Akinyeye Yomi, (2003) Nigeria and the Wider World in the 20 th century: Essays in Honour of Professor Akinjide Osuntokun, Ibadan: Davidson Press.

Alander, (1992), The NGOS: Examining Non State Actors, Boston.

Baike, A. and Omoregie, O.S.B. (1989), "University Education: Policies and Programmes Perspectives of an Educationist and Planner” in Tamuno, T.N. and Atanda, J.P. (eds) , Nigeria since Independence: The First 25 Years Ibadan: Heinemann Educational Books Nigeria Limited.

Federal Government of Nigeria: National Library Bill, Supplement to Official Gazette No.70, Vol.51, $5^{\text {th }}$ September, 1964, Part C.

Ford Foundation Report (2001-2005), The Funding of the Africa Higher Education Initiatives in West AFRICA Circa 2001-2005.

Franklin Book programmes, Inc., A Book Development Project In Nigeria, 1964-1968: Final Report submitted to the Ford Foundations, New York: Franklin Books Programme Inc.

Goldstein, J.S. \& Pevehouse, J.C. (2006), International Relations $\left(7^{\text {th }}\right.$ Edition), New York: Pearson, Longman.

Hanza, Alavi (1996), Functions of NGOS, New York: Hilcrest

Kotas, T. \& Chritos, F. (1996), The Origins, Organizations and Policies of NGOS: Assessment, Emerging Trends and Prospects in the Developing Countries, Athens.

Lagos State University (2000-2002) Faculty of Arts, Department of History and International Studies, Departmental Brochure.

Nduka, Otonti (1964), Western Education and the Nigerian Cultural Background, Ibadan: University Press Limited.

Ojo, O. \& Sesay, A. (1988), Concepts in International Relations Lagos: JAD Publishers.

Robert, J.A \& Robert, Jevis (1993), International Politics: Enduring Concept and Contemporary Issues ( $6^{\text {th }}$ ed.) Eaglewood Cliffs:

Taiwo, C.O. (1980), The Nigerian Education System, Past, Present and Future, Ikeja, Lagos: Thomas Nelson (Nigeria) Limited.

Tamuno, Tekena N. and Atanda, J.A (eds) (1989), Nigeria Since Independence: The First 25 Years, Ibadan: Heinemann Educational Books Nigeria Limited.

Williams, Grace Alele (2000), Capacity Building Among Women and the Girl Child: The Role of FAWEN, a paper presented at a two day seminar, organized by the Delta State Branch of the Forum of African Women Educationists (FAWEN) November $29^{\text {th }}$.

\section{Oral Sources}

Oral Interview with late Ojeyemi Ezekiel, aged 75years, LASU Stores, October 2007. 
Oral Interview with Thomas Dapo, Aged, 50+, an ex-student of Aiyetoro Comprehensive High School, Aiyetoro, department of History and International Studies, Lagos State University, Ojo, Lagos, Nigeria.

Oral Interview with Williams, Grace Alele, aged 80+ at her Surulere home, Lagos, August 2005.

http://www.fordfound.org/elibrary/documents/o221/supress/low/0221supplow.pdf 